Until quite recently no attempt to separate the somatic antigens from the bacterial cell had been successful, but within the last ten years several methods for the isolation of fully active bacterial antigens from Gram negative organisms have been elaborated. The earliest practical method to accomplish this was introduced by Boivin, who extracted bacteria at $0^{\circ}$ with $0.2 \mathrm{~N}$. trichloracetic acid $(p \mathrm{H}$ $1 \cdot 0-2 \cdot 0)$. The extract was apparently free from intact protein and was powerfully antigenic. At about the same time and quite independently, Raistrick and Topley found that by the action of trypsin on certain bacteria it was possible to bring the antigenic complex into solution. The digestion was carried out at $p \mathrm{H} 8 \cdot 2-8 \cdot 5$ for several days at $37^{\circ}$. Methods of isolation that depend on extraction of the bacteria with cold anhydrous organic solvents, such as diethyleneglycol, in which native proteins and many bacterial somatic substances are insoluble, have also been successfully employed to isolate these important biological complexes.

It is certain that as our knowledge of the nature of the bacterial somatic antigens grows, we shall find very different types of chemical structures associated with bacterial and tissue antigenic complexes. We already know, however, that certain groups of bacteria possess antigens that are built up from similar types of molecules arranged together as polymolecular aggregates. As an example of this similarity in structure the $O$ somatic antigens of Bact. typhosum and Bact. dysenterice (Shiga) may be mentioned. Each antigen is built up of a polysaccharide, specific for the organism and responsible for its characteristic serological reactions, and a polypeptide-like com. ponent (most probably a conjugated protein). Other components of the native antigenic complex, such as phospholipin, also occur, and it is possible that further unidentified substances are present.

In certain instances, however, it has been shown that of all the components present in the native antigenic complex only two, the polysaccharide and protein, are essential for the manifestation of antigenicity. It seems probable, therefore, that a bacterial antigen as it exists in the intact bacterial cell is not a simple compound of rigid chemical composition, but consists of a labile molecular aggregate possessing an essential component-such as a polysaccharide-of definite chemical structure and of fixed composition, which determines the strict specificity of the antigen, together with other loosely bound constituents which endow the essential component with antigenic properties. Only part of these physically associated molecules are necessary for the manifestation of the specific antigenic properties, and certain of these constituents can be dissociated from the labile complex during the isolation and purification of the antigen without producing more than a moderate reduction in the antigenic capacity of the active material. More thorough physical disaggregation of the polymolecular complex into single types of molecules will lead to complete loss of the original antigenicity that gives rise to the homologous immune body.

Considerable support for this conception of antigenic structure was obtained when it was observed that the isolated and undegraded specific polysaccharide component of the antigen could be re-combined with the conjugated protein component, under almost physiological conditions, to form an antigenic complex that would give rise to antibodies specific for the polysaccharide component of the newly formed complex. Neither component showed any specific antigenic properties when tested alone. Furthermore, it has been found that the non-antigenic, specific polysaccharide of one organism will form an antigenic complex when combined with the conjugated protein component derived from the corresponding somatic antigen of another organism that belongs to an entirely different bacterial species. The nature of the bonds that hold the different types of molecules together as a polymolecular aggregate is unknown. Future work will certainly decide whether the association of the various component molecules is due to 'salt-like linkages', hydrogen bonds, van der Waals' forces or to some as yet unknown mechanism. It can only be stated at the present time that the forces concerned give rise to an aggregate with sufficient stability to make it behave as an independent molecular species.

Further evidence in support of these ideas on antigenic structure is derived from the success with which certain non-antigenic polysaccharides of both vegetable and animal origin have been converted to full antigens by combination with the reactive bacterial conjugated protein mentioned above. The artificial antigens again give rise to immune body that reacts specifically with the polysaccharide component used to build the antigenic complex.

Antibodies against the polysaccharides agar-agar, cherry gum and gum acacia have been described, and more recently immune sera capable of specifically agglutinating human $A$ red blood cells but not those of groups $B$ and $O$ have been prepared by combining a naturally occurring but non-antigenic polysaccharide complex that possesses blood group $A$ specificity with a bacterial somatic conjugated protein. It is believed that these powerful anti- $A$ sera will be useful in certain blood-group determinations and will prove to be of value in the technique of differential agglutination.

It is clear that bacterial and tissue antigens that are largely polysaccharide in nature belong to a class of substances that are characterized as large molecules'. They display unusual properties and it will be necessary to develop new methods for handling them and new chemical conceptions to explain their nature and function.

\section{RADIO RESEARCH ON METRE WAVES}

$\mathrm{T}$ HREE papers by members of the staff of the Radio Department of the National Physical Laboratory appear in the March issue of the Pro. ceedings of the Wireless Section of the Institution of Electrical Engineers.

The first paper, on a study of the propagation of ultra-short waves between Guernsey and England, by Dr. R. L. Smith-Rose and Miss A. C. Stickland, was referred to in NATURE of January 2, p. 31.

Following this is a paper by Messrs. F. M. Colebrook and A. C. Gordon-Smith, entitled "The Design of Ultra-Short Wave Field-Strength Measuring Equipment". This comprises a description of the essential features of design and construction of apparatus for measuring field-strength, and suitable for any radiofrequencies between 30 and 600 megacycles per second; that is, wave-lengths between 10 and 0.5 metres. The equipment is of a relatively narrow 
band width type (about $20 \mathrm{kc} . / \mathrm{s}$.), and is primarily intended for the measurement of continuous-wave fields of the order of tens or hundreds of microvolts per metre. The description is supplementary to a previous paper on the subject which dealt with measurements at wave-lengths down to about 7 metres. For shorter wave-lengths than this, a halfwave-length dipole is the most practicable form of aerial, and this is coupled to the frequency-change unit by a flexible transmission line. For wavelengths less than about one metre, it is an advantage, from the viewpoint of ease of operation and increase in sensitivity, to use a flat sheet reflector behind tho aerial, together with a shorter transmission line. The frequency change unit incorporates a diode, and it is convenient to operate the local oscillator at one half or one third of the signal frequency.

The measurements made with this equipment rest ultimately upon the intermediate-frequency amplifier, which can be calibrated for gain over a wide range. Such calibrated amplifiers have been developed at the National Physical Laboratory, and used extensively for field work : an improved version has been developed for laboratory work, and the more important features of this have been incorporated in a commercial form of the field equipment. In operation at the higher frequencies, it has been found necessary that the complete assembly should be thoroughly screened: the batteries are contained in a separate metal box and connected to the amplifier and frequency-change units by screened flexible leads and screened plugs. The overall calibration of the complete equipment is carried out by the measurement of a known, preferably horizontally polarized, field produced by a radiation method described in a previous publication.

The third paper in the series is by Dr. J. S. McPetrie and J. A. Saxton, and is entitled "The Determination of the Electrical Properties of Soil at a Wave-length of 5 Metres (Frequency $60 \mathrm{Mc} / \mathrm{s.}$.)". This gives an account of experiments made to determine the electrical properties of various ground surfaces from the reflexion coefficient obtained for radiation at normal incidence. The experimental technique used a horizontal transmitting aerial set at a height of about $12 \mathrm{~m}$. above the ground; and the stationary wave pattern formed between this aerial and the ground was explored by observing the current induced in a horizontal receiving dipole placed at various heights. The observed results showed good agreement with theoretical curves calculated on the assumption that reflexion takes place actually at the ground surface. The sites investigated varied from wet clay to gravel ; the corresponding values of dielectric constant ranged from about 5 to 60 , while the values of conductivity varied from less than $10^{8}$ up to, but not greater than, $10^{9}$ E.S.U.

The lowest values in each case refer to a site which had been excavated to a depth of seven feet, exposing a surface of pure gravel, with no sign of humus or decayed vegetation. A nearby undisturbed site on the same subsoil, but with about nine inches of grasscovered soil on top, gave a reflexion coefficient similar to that obtained on other grass-covered sites. The above values of the electrical constants obtained with undisturbed soil agree with those measured in the laboratory for samples of similar types of soil. The experiments were made during winter months under rather wet conditions: the values of both dielectric constant and conductivity would probably be less during the summer.

\section{FORTHCOMING EVENTS}

\author{
Friday, July 16-Monday, July 19
}

Assochation of University Professors and Lecturers of the ALIIED CodNTRIES IN GREAT BRITAIN (at New College, Oxford).

Saturday, July 17

At 9.45 a.m.-Separate Meetings of Sections.

At 2.30 p.m.-Collective Groups of Meetings.

Sunday, July 18

At 10 a.m.-General Meeting.

Monday, July 19

At 10 a.m.- International University Conference of the Association of University Teachers.

\section{Wednesday, July 21}

Instinute of FUex (in the James Watt Memorial Institute, Great Charles Street, Birmingham), at 2.30 p.m.-Mr. L. W. Andrew and Dr. E. A. C. Chamberlain : "Radiant Heat for Industrial Processes"Infra-red' by Gas".

\section{Friday, July 23}

Royal Aeronatical Society (at the Institution of Mechanical Engineers, Storey's Gate Westminster, London, S.W.1); at 5.30 p.m. Engineers, Storey's Gate, Westminster, London, S.W.1), at 5.30

\section{APPOINTMENTS VACANT}

APPLICATIONs are invited for the following appointments on or before the dates mentioned:

SpeEch Therapist (full-time)-The School Medical Officer, Town Hall, Ealing, London, W.5 (July 22).

Responsible Teacher of Engineering in the Batley Technical College and School of Art-The Director of Education, Education Offices, Batley, Yorks. (July 22).

A post on the Chemical Research Staff of the Tin Research Institute-The Secretary, Tin Research Institute, Fraser Road, Greenford, Middx. (July 24).

COMBINED POST OF FULL-TIME (ACTING) RADIOTHERAPIST TO THE LIVERPOOL CANCER CONTROL ORGANIZATION and (ACTING) MEDICAL DIRECTOR OF THE RADIOTHERAPEUTIC DEPARTMENT OF THE LIVERPOOL RADIUM INSTITUTE-The Hon. Secretary, Liverpool

HEADMASTER OF THE DAY School attached to the South-West Essex Technical College and School of Art, Walthamstow-The Chief Education Officer, County Offices, Chelmsford (July 24).

WOMEN Psychiatric Social Workers at the Birmingham Child Guidance Clinjc-The Chief Education Officer, Education Office, Margaret Street, Birmingham 5 (endorsed 'Psychiatric Social Worker') (July 29).

General Manager and Engineer of the Sheffield Water UNDERTALING-The 'Town Clerk, Town Hall, Sheffield 1 (July 31 ). SPEECH THERAPIST (full-time)-The Secretary for Education, Educa. tion Offices, York (August 6)

CHEmist AND ASSAYER on the establishment of the South African Mint, Pretoria-The Secretary, Office of the High Commissioner for the Union of South Africa, South Africa House, Trafalgar Square, London, W.C.2 (August 31).

Heads of the Departments of Physiology, Medicine, and HEADS OF THE DEPARTMENTS OF Pring College and Hospital, at The University, Reading (October 1).

Chair of Naval ARdhitecrure-The Acting Secretary of University Court, The University, Glasgow (October 4).

Science AND Mathematics Master at the English High School for Boys, Istanbul-The British Council, 3 Hanover Street, London, W. (endorsed 'Istanbul').

ANALYST AND ANIMAL NUTRITION Assistant (temporary)-The ANALYST AND ANIMAL NoTrition Aoliege, Newport, Shropshire. Psychiatric Socral Worker-The Medical Superintendent, Springfield Mental Hospital, Tooting, London, S.W.17.

Teacher of Mathematics and Scrence in the Junior Technical School (temporary)-The Clerk to the Governors, North-East Essex Technical College and School of Art, Colchester.

ASSISTANT ENGINEER for the Government of Northern Rhodesia Public Works Department-Ministry of Labour and National Service, Public Works Department-Minis) Register (Reference E.697), Alex. andra House, Kingsway, London, W.C.2.

ENGINEER (MECHANICAL) to carry out work of national importance -The Ministry of Labour and National Service, Central (Technic and Scientific) Register (Reference No. C.1660), Alexandra House Kingsway, London, W.C.2.

Industrial Planning Officers (9) (Reference No. C.1771), an Assistant Industrial, Planning Officers (6) (Reference No. C.1772) for the Aeronautical Division of the Department of Supply of the Government of India-The Ministry of Labour and National Service, Central (Technical and Scientific) Register (quoting appropriate Reference No.), Alexandra House, Kingsway, London, W.C.2. 